\title{
Which smoking cessation aids are proven effective according to smokers who want to quit smoking? A report from the Netherlands
}

Citation for published version (APA):

Willems, R. A., Willemsen, M. C., Smit, E. S., Nagelhout, G. E., Janssen, E., \& de Vries, H. (2014). Which smoking cessation aids are proven effective according to smokers who want to quit smoking? A report from the Netherlands. Tobacco Control, 23(6), 525-526. https://doi.org/10.1136/tobaccocontrol-2013051076

Document status and date:

Published: 01/11/2014

DOI:

10.1136/tobaccocontrol-2013-051076

Document Version:

Publisher's PDF, also known as Version of record

Document license:

Taverne

Please check the document version of this publication:

- A submitted manuscript is the version of the article upon submission and before peer-review. There can be important differences between the submitted version and the official published version of record.

People interested in the research are advised to contact the author for the final version of the publication, or visit the DOI to the publisher's website.

- The final author version and the galley proof are versions of the publication after peer review.

- The final published version features the final layout of the paper including the volume, issue and page numbers.

Link to publication

\footnotetext{
General rights rights.

- You may freely distribute the URL identifying the publication in the public portal. please follow below link for the End User Agreement:

www.umlib.nl/taverne-license

Take down policy

If you believe that this document breaches copyright please contact us at:

repository@maastrichtuniversity.nl

providing details and we will investigate your claim.
}

Copyright and moral rights for the publications made accessible in the public portal are retained by the authors and/or other copyright owners and it is a condition of accessing publications that users recognise and abide by the legal requirements associated with these

- Users may download and print one copy of any publication from the public portal for the purpose of private study or research.

- You may not further distribute the material or use it for any profit-making activity or commercial gain

If the publication is distributed under the terms of Article 25fa of the Dutch Copyright Act, indicated by the "Taverne" license above, 


\section{Which smoking cessation aids are proven effective according to smokers who want to quit smoking? A report from the Netherlands}

The use of evidence-based smoking cessation aids (SCA) is an important strategy in helping smokers to quit successfully and is highly recommended for smoking cessation. ${ }^{1}$ However, the use of these aids in the Netherlands is particularly low. ${ }^{2}$ While many smokers seem to underestimate the benefits of using evidence-based SCA, ${ }^{3}$ the use of non-evidence-based SCA is quite popular. ${ }^{4}$ Smokers do not perceive non-evidence-based SCA to be less helpful than evidence-based SCA. ${ }^{6}$ The internet might contribute to this misperception, since internet searches for SCA more often lead to non-professional than professional websites. ${ }^{8}$ So do smokers know which SCA are evidence-based and which are not? This study sought to find an answer to this question.

The data collected in September 2010 were part of a study administered by the research agency MarketResponse. Adult smokers were randomly selected for participation from a large research panel. Of the 4338 smokers who were contacted, 2673 smokers $(61.6 \%)$ responded. Of these smokers, 668 (25.0\%) intended to quit within half a year and were included in the analysis. Knowledge about the effectiveness of 10 different SCA was measured by asking, 'Which smoking cessation aid is, according to you, proven effective?'
Mean age of the respondents was 45.5 years $(\mathrm{SD}=14.1)$; $53.0 \%$ were men. Mean number of cigarettes per day was $12.62(\mathrm{SD}=8.00)$. Table 1 shows respondents' reporting on the evidence base for each smoking cessation aid. In general, more smokers reported that SCA were not proven effective than proven effective. At least one out of three smokers indicated that they did not know whether a certain aid was proven effective. While nicotine replacement therapies, acupuncture and advice to quit from a general practitioner (GP) were known by almost every smoker, stop-smoking medications were unfamiliar to about half of the smokers.

The results of this study indicate that Dutch smokers who intend to quit smoking have a rather low level of knowledge about the evidence base of SCA. A striking finding was that what smokers indicated to be proven effective seemed irrespective of the actual evidence base of SCA. This might be explained by the intensive promotion of ineffective commercial cessation methods, resulting in a situation where smokers cannot distinguish correctly between evidence-based and nonevidence-based SCA. It should also be noted that respondents might have had different interpretations of what 'proven effective' actually means. It would be advisable for future research to include an introductory message explaining what is meant by proven effectiveness. More research is also needed to examine whether our results are generalisable to countries with higher use of SCA. However, it seems that-at least in the Netherlands-action is needed to increase smokers' knowledge of the evidence base of SCA. Such action could be a referral of smokers regarding the use of effective SCA by GPs, because our data indicate a relatively high confidence in the advice from their GP. Unfortunately, advice from a GP or other professionals to quit smoking is relatively low in the Netherlands. ${ }^{2}$

\section{What this paper adds}

- This study demonstrates that smokers who intend to quit smoking have a rather low level of knowledge about the evidence base of different smoking cessation aids (SCA).

- The general practitioner (GP) could play a key role in educating about the effectiveness of SCA, since these smokers report a relatively high confidence in the advice from their GP. 
Table 1 Percentages of responses to the question 'Which smoking cessation aid is, according to you, proven effective?' ( $n=668)$

\begin{tabular}{lllll}
\hline Cessation aid & Proven effective & Not proven effective & Never heard of & Don't know \\
\hline Evidence-based SCA & & & & \\
Nicotine gum & 16.5 & 43.9 & 1.6 & 38.0 \\
Nicotine patch & 26.8 & 36.9 & 1.1 & 35.2 \\
Nicotine lozenge & 17.2 & 35.5 & 6.0 & 41.3 \\
Zyban/Bupropion & 10.5 & 9.3 & 45.9 & 34.3 \\
Champix/Varenicline & 6.2 & 7.5 & 51.8 & 34.4 \\
Advice to quit from GP & 30.5 & 22.6 & 4.6 & 42.3 \\
Telephonic coach & 8.1 & 27.6 & 18.9 & 45.3 \\
Non-evidence-based SCA & & & & 34.2 \\
Allen Carr methodt & 13.7 & 30.1 & 22.0 & 36.0 \\
Acupuncture & 23.6 & 36.6 & 3.8 & 39.0 \\
Laser treatment & 17.8 & 28.9 & 14.4 & \\
\hline
\end{tabular}

${ }^{*}$ A smoking cessation aid was considered evidence-based when the results were obtained from (a systematic review containing) randomised comparative studies of good quality (randomised, double-blind, controlled studies), sufficient size and consistency. ${ }^{1}$

tThe Allen Carr method includes a book and group therapy. No randomised controlled trials were found with respect to this method.

GP, general practitioner; SCA, smoking cessation aids.

Roy A Willems, ${ }^{1,2}$ Marc C Willemsen, ${ }^{2,3}$ Eline S Smit, ${ }^{2}$ Gera E Nagelhout, ${ }^{2,3}$ Eva Janssen, ${ }^{2}$ Hein de Vries ${ }^{2}$

${ }^{1}$ School of Psychology, Open University of the Netherlands, Heerlen, The Netherlands

${ }^{2}$ Faculty of Health Medicine and Life Sciences, Department of Health Promotion, School for Public Health and Primary Care (CAPHRI), Maastricht University, Maastricht, The Netherlands ${ }^{3}$ STIVORO, Dutch Expert Centre on Tobacco Control, The Hague, The Netherlands

Correspondence to Roy A Willems, School of Psychology, Open University of the Netherlands, P.O. Box 2960, 6401 DL Heerlen, The Netherlands; roy.willems@ou.nl

Acknowledgements We would like to thank Tarquínia Zeegers and Bas van den Putte for their contribution in setting up the study.

Contributors RW conducted the statistical analyses and drafted the manuscript. MW, GN and HdV contributed to the design of the study. All authors revised the manuscript critically for important intellectual content and read and approved the final manuscript.

Funding This work was supported by ZonMw grant number 50-51300-98-010.

Competing interests None.

Ethics approval The Central Committee on Research Involving Human Subjects in the Netherlands requires no ethical approval for non-medical survey research.

Ethics approval ZonMw.

Provenance and peer review Not commissioned; externally peer reviewed.

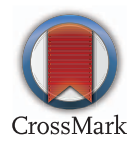

To cite Willems RA, Willemsen MC, Smit ES, et al. Tob Control 2014;23:525-526.

Accepted 2 July 2013

Published Online First 22 July 2013

Tob Control 2014;23:525-526.

doi:10.1136/tobaccocontrol-2013-051076

\section{REFERENCES}

1 Partnership on smoking cessation. Guideline treatment of tobacco dependence. Alphen aan den Rijn, The Netherlands: Van Zuiden Communications, 2006.

2 Borland R, Li L, Driezen P, et al. Cessation assistance reported by smokers in 15 countries participating in the International Tobacco Control (ITC) policy evaluation surveys. Addiction 2012;107:197-205.

3 Hammond D, McDonald PW, Fong GT, et al. Do smokers know how to quit? Knowledge and perceived effectiveness of cessation assistance as predictors of cessation behaviour. Addiction 2004;99:1042-8.

4 Sood A, Ebbert JO, Sood R, et al. Complementary treatments for tobacco cessation: a survey. Nicotine Tob Res 2006:8:767-71.

5 Willems RA, Willemsen MC, Nagelhout GE, et al. Understanding smokers' motivations to use evidence-based smoking cessation aids. Nicotine Tob Res 2013;15:167-76.

6 de Zwart KM, Sellman JD. Public knowledge and attitudes regarding smoking and smoking cessation treatments. N Z Med J 2002:115: 219-22.

7 McMenamin SB, Halpin HA, Bellows NM. Knowledge of Medicaid coverage and effectiveness of smoking treatments. Am J Prev Med 2006;31:369-74.

8 Cobb NK. Online consumer search strategies for smoking-cessation information. Am J Prev Med 2010:38:S429-32 